\title{
The influence of exendin-4 intervention on non-obese diabetic mouse blood and the pancreatic tissue immune microenvironment
}

\author{
JINSHUI HE, CHAOWEI LIAN, YANLING FANG, JINZHI WU, HUOWANG ZHOU and XIAOLING YE \\ Department of Pediatrics, Zhangzhou Hospital Affiliated to Fujian Medical University, \\ Zhangzhou, Fujian 363000, P.R. China
}

Received May 17, 2016; Accepted September 6, 2016

DOI: $10.3892 / \mathrm{etm} .2016 .3694$

\begin{abstract}
The aim of the study was to determine the influence of exendin-4 intervention on non-obese diabetic (NOD) mouse blood and the pancreatic tissue immune microenvironment. A total of 40 clean NOD mice were used in the study and randomly divided into 4 groups ( $n=10$ /group). The first group was blank control group D with normal saline intervention, and with different doses of exendin, i.e.,-4 2, 4 and $8 \mu \mathrm{g} / \mathrm{kg} /$ day. The three remaining groups were: i) Low-dose group A; ii) medium-dose group $\mathrm{B}$; and iii) high-dose group $\mathrm{C}$. Mice in the four groups went through intervention for 8 weeks. Their mass and blood glucose levels were tested each week. After 8 weeks, the mice were sacrificed, and mouse serum samples were reserved. The ELISA method was used to test peripheral blood (PB), IL-2, IFN- $\gamma$ and IL-10 levels. Pancreatic samples were created. Immunohistochemistry was used to observe the infiltration degree of mouse pancreatitis and the local expression state of pancreatic IL-10. Mouse pancreatic tissues were suspended in pancreatic cell suspension. Flow cytometry was used to test the state of T-cell subsets CD4 and CD25. Mouse pancreatitis in control group D was mainly at grade 2 and 3 . Under a light microscope, it was observed that pancreatic cell morphology was in disorder, and the size and quantity of the pancreas was small. Mouse pancreatitis in the exendin-4 low-dose group A, medium-dose group B and high-dose group $\mathrm{C}$ was mainly at grade 0 and 1 . Under a light microscope, it was observed that pancreatic cell morphology improved, the infiltration degree of lymphocyte was improved and pancreatic islet size was restored somewhat. Additionally, a few brownish granules were identified within the pancreatic sample cells in control group D. There were many brownish
\end{abstract}

Correspondence to: Dr Xiaoling Ye, Department of Pediatrics, Zhangzhou Hospital Affiliated to Fujian Medical University, 55 Shengli West Road, Zhangzhou, Fujian 363000, P.R. China E-mail: ye_xiaoling1@163.com

Key words: exendin-4, NOD mice, diabetes, immune microenvironment granules with deep color within the pancreatic sample cells in exendin-4 low-dose group A, medium-dose group B and high-dose group C. IL-10 immunohistochemistry scores in the low-dose group A, medium-dose group B and high-dose group $C$ were $3.82 \pm 0.72,4.34 \pm 0.86$ and $4.81 \pm 0.94$, respectively, and were higher than the score of $2.25 \pm 0.63$ in control group D. CD4+CD25+T-cell proportions in mouse pancreatic tissues of low-dose group A, medium-dose group B and high-dose group $\mathrm{C}$ were $5.31,5.53$ and $5.74 \%$, respectively, which were higher than that of the CD4+CD25+T-cell proportion $(1.62 \%$ in control group $\mathrm{D})$. The CD4+CD25 $5^{\text {high }} \mathrm{T}$-cell proportion in CD4+T-cells in group A, B and C increased. Compared with control group D, serum IL-10 levels in the exendin-4 low-dose group A, medium-dose group B and high-dose group C increased $(\mathrm{P}<0.05)$, while levels of IL-2 and IFN- $\gamma$ decreased $(\mathrm{P}<0.05)$. Additionally, the difference of serum IL-10, IL-2 and IFN- $\gamma$ levels in the low-dose group A, medium-dose group B and high-dose group $\mathrm{C}$ was of statistical significance $(\mathrm{P}<0.05)$. Exendin-4 intervention can increase quantities of CD4 and CD8+T cells in NOD mouse pancreases, with PB IL-10 expression and local expression of IL-10 in pancreatic tissues. It also can inhibit the expression of serum IL-2 and IFN- $\gamma$, regulate the organism immune microenvironment and prevent diabetes. CD $4+C D 25^{\text {high }} \mathrm{T}$ cells increase in NOD tumor infiltration lymphocytes mediated by exendin- 4 intervention, which may be related to the fact that exendin- 4 inhibits the lethal effect of CD8+T cells through contact among cells and eventually exerts immunosuppressive effect.

\section{Introduction}

Type 1 diabetes is an autoimmune disease, and the prominent population affected by the disease is teenagers. In recent years, the number of individuals diagnosed with the disease has increased. Once affected by the disease, the patient undergoes lifelong insulin treatment, which can pose an economic burden to the patient and family. Patients with type 1 diabetes suffer from multiple complications, which can lead to disabling and lethal factors (1).

To the best of our knowledge, few studies are available on the exact pathogenesis of type 1 diabetes, the variation of patient blood and the pancreatic tissue immune microenvironment (2-4). 
Non-obese diabetic (NOD) mice can spontaneously generate autoimmune disease, and their pathogenic process is similar to that of type 1 diabetes of human beings. Consequently, a NOD rodent animal model should be established to probe into morbidity and develop a treatment intervention mechanism for human type 1 diabetes (5). Exendin- 4 is a type of polypeptide hormone separated from Gila monster saliva. This hormone is a broad application prospect in treating type 2 diabetes $(6,7)$. However, there is little research or studies on exendin-4 as an intervention mechanism in type 1 diabetes treatment. In order to determine the influence of exendin-4 intervention on NOD mouse blood and the pancreatic tissue immune microenvironment, a NOD mouse model was established for the experiments. A variation in T-cell subset CD8, CD4 and CD25 in NOD mouse peripheral blood and pancreatic tissue, as well as in the contents of cell factors IL-2, IFN- $\gamma$ and IL-10 after low-dose, medium-dose and high-dose exendin-4 intervention was observed.

\section{Materials and methods}

Materials. A total of $40 \mathrm{NOD} / \mathrm{Lt}$ mice were purchased from the Institute of Experimental Animals of the Chinese Academy of Medical Sciences. There were 20 male and 20 female mice, with a weight of 17-25 g. Exendin-4 reagent (Kangtai Biotechnology, Beijing, China); hematoxylin and eosin (H\&E) dye liquor (Beijing Solarbio Science and Technology, Co., Ltd., Beijing, China); IL-2, IL-10 and IFN- $\gamma$ reagent kits (Shanghai Biotechnology, Shanghai, China); monoclonal CD4 rabbit antibody (Abcam, Cambridge, MA, USA; catalog no.: ab133616; dilution, 1:100) and monoclonal CD8 rabbit antibody (Abcam; catalog no.: ab22378; dilution, 1:100); a flow cytometer (Beijing Kexue Yingye Science and Technology Development, Beijing, China); microplate reader (Jinan Guangyao Medical Equipment, Jinan, China); centrifugal machine (Shanghai Puyuan Instrument, Shanghai, China); and an optical microscope (Shenzhen Final Technology, Shenzhen, China) were used in the study.

The present study was approved by the ethics committee of Fujian Medical University (Fujian, China).

Methods. A random number table was used to divide 40 clean and healthy NOD mice into 4 groups ( $n=10 /$ group) as follows: One blank control group D with normal saline intervention, and the remaining three groups with exendin-4 intervention. According to the different exendin- 4 doses of 2, 4 and $8 \mu \mathrm{g} / \mathrm{kg} / \mathrm{day}$, they were called the low-dose group A, medium-dose group B and high-dose group C, respectively. The four groups of mice were intervened for 8 weeks, after which they were sacrificed by cervical dislocation. An inner canthus method was used to take $\sim 1 \mathrm{ml}$ of whole blood, which was then centrifuged at $5,000 \mathrm{xg}$ for $10 \mathrm{~min}$ at $4^{\circ} \mathrm{C}$. Serum was kept at $-20^{\circ} \mathrm{C}$ to test serum IL-2, IL-10 and IFN- $\gamma$. Pancreatic tissues were selected to conduct T-cell subset determination, while other subsets continued to be observed.

Observation of pancreatitis infiltration degree. Pancreatic samples were embedded with paraffin, and then turned into tissue sections with H\&E dyeing to be observed under a light microscope (Olympus, Tokyo, Japan). Pathology personnel used a double-blind method to determine the infiltration degree of pancreatitis. The grade of pancreatitis infiltration degree was divided as follows: i) Grade 0: Pancreas islet was complete without lymphocyte infiltration; ii) grade 1: lymphocytes infiltrated around the pancreas islet or $<25 \%$ pancreas islet area was affected; iii) grade 2: $25-50 \%$ pancreas islet area was affected; and iv) grade $3:>50 \%$ pancreas islet area was affected. According to the above grading standard, the pancreatic sections of the four groups were observed under a x5-x400 microscope.

Assessment of local expression of pancreatic IL-10. Immunohistochemistry was used to observe the expression of the $I L-10$ gene in local pancreatic samples. Brownish granules in cytoplasm were considered positive cells. Positive cell percentage and dyeing intensity were calculated. The positive cell percentage was calculated as: i) $<1 \%$ was 0 ; ii) $1-10 \%$ was 1; iii) $11-50 \%$ was 2 ; iv) $51-80 \%$ was 3 ; and v) $>80 \%$ was 4 . The dyeing intensity of granules was calculated as: i) No dyeing was 0 ; ii) faint yellow was 1 ; iii) yellow was 2 ; and iv) brown was 3 . The product of positive cell percentage and dyeing intensity determined the immunohistochemistry score as follows: 0 score (-); 1-4 scores (+); 5-8 scores (++); and 9-12 scores (+++).

Determination of pancreatic tissue T-cell subset. After the mice were sacrificed, they were sterilized with alcohol. Pancreatic tissues were separated through an aseptic technique. Nearby connective tissues and pancreatic tissues were removed and rinsed twice in Hanks' liquid. Ophthalmic scissors were used to cut the tissues into pasty sections. A tip sucker was used to blow and disperse pancreatic cells, while a 300-mesh net was used to implement infiltration. A lymphocyte-separating medium was used to extract lymphocytes at rotating speeds of $400 \mathrm{x}$ g. They were then centrifuged for $20 \mathrm{~min}$. The suspended layer of lymphocytes was extracted after a $2 \mathrm{ml} \mathrm{pH} 7.4$ phosphate buffer saline (PBS) working solution was added. The lymphocytes were centrifuged for $5 \mathrm{~min}$ at $800 \mathrm{x} \mathrm{g}$. The supernatant was discarded, and the cell concentration was adjusted to $2 \times 10^{9}$ cells/l. Under a microscope, $0.4 \%$ trypan blue was used to count living cells. The cell survival rate was determined to be $>95 \%$. A $100 \mu 1$ pancreatic single-cell suspension at a concentration of $2 \times 10^{9} / \mathrm{ml}$ was measured at $25^{\circ} \mathrm{C}$ and kept in the dark. The suspension was then incubated with $10 \mu \mathrm{l} \mathrm{CD8-FITC} \mathrm{and} 10 \mu \mathrm{l} \mathrm{CD} 4-P E$ fluorescent antibody for $15 \mathrm{~min}$. A 2-m erythrocyte lysate buffer was added to the suspension to incubate it for $10 \mathrm{~min}$. A 2-ml PBS solution was then added to conduct centrifugation at $800 \mathrm{x}$ g for $5 \mathrm{~min}$. PBS washing was then repeated twice (the method used before), the supernatant was removed, and $200 \mu \mathrm{l}$ PBS solution was added to each tube to conduct FCM detection. Macintosh (Apple, Inc., Cupertino, CA, USA) was the data processing system used. Cells were analyzed using CellQuest software (BD Biosciences, San Jose, CA, USA). Grating was conducted on lymphocytes on forward and lateral angular scattering diagrams. A logarithmic method was used to acquire fluorescence signals before $1 \times 10^{4}$ cells were taken and analyzed under the same software. Serum of IL-2, IL-10 and IFN- $\gamma$ were determined using ELISA. Operating steps were performed with ELISA reagent kits of IL-2, IL-10 and IFN- $\gamma$. The samples were determined in the same batch. 


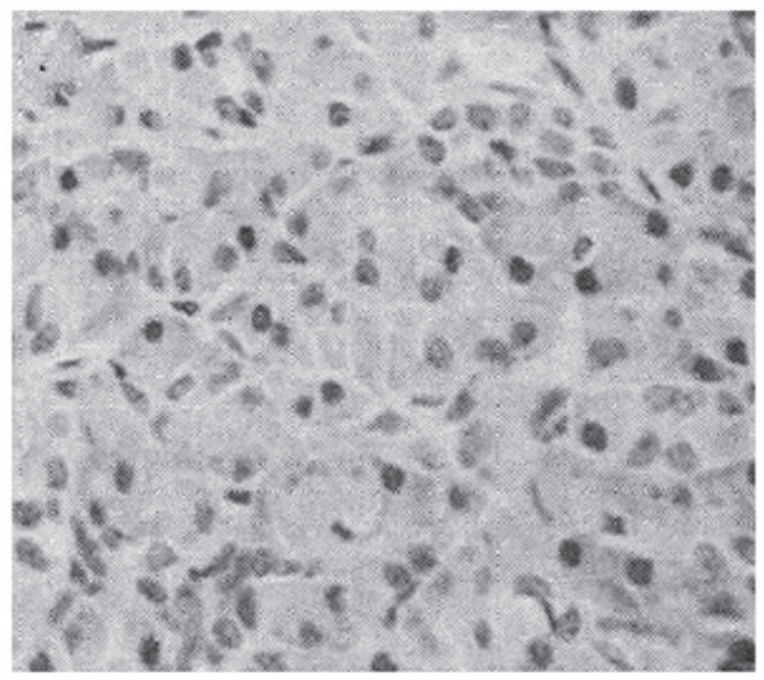

Figure 1. IL-10 local expression in pancreatic tissues (hematoxylin and eosin, x400) of mice in low-dose group A.

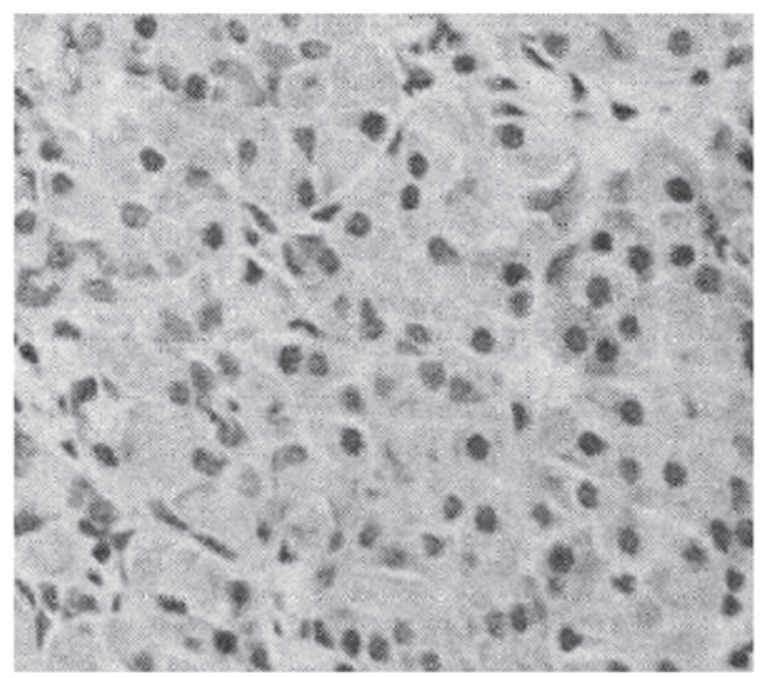

Figure 2. IL-10 local expression in pancreatic tissues (hematoxylin and eosin, $\mathrm{x} 400$ ) of mice in medium-dose group B.

Statistical analysis. SPSS 21.0 statistical software (IBM SPSS, Armonk, NY, USA) was used to conduct statistical analysis. Experimental data were presented as mean \pm standard deviation, t-test or $\mathrm{t}^{\prime}$-test. A $\chi^{2}$ test was conducted on experimental results. $\mathrm{P}<0.05$ was considered to indicate a statistically significant difference.

\section{Results}

Pancreatitis infiltration degree. Pancreatitis of mice in control group D was mainly at grade 2 and 3 . Under a light microscope, it was observed that pancreatic cell morphology was in disorder, and the size and quantity of the pancreas was small. Mouse pancreatitis in exendin-4 low-dose group A, medium-dose group B and high-dose group $\mathrm{C}$ was mainly at grade 0 and 1 . Under the light microscope, it was observed that pancreatic cell morphology improved, infiltration degree

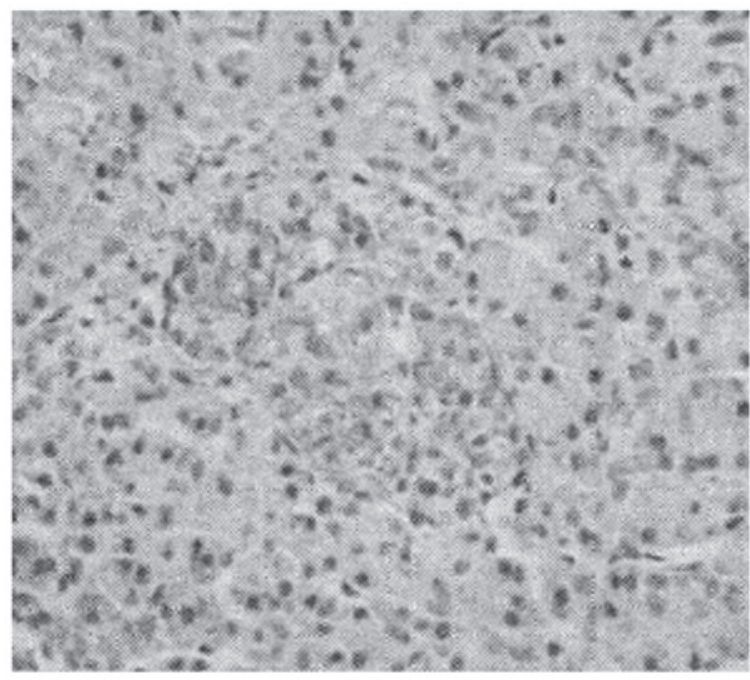

Figure 3. IL-10 local expression in pancreatic tissues (hematoxylin and eosin, $\mathrm{x} 400$ ) of mice in high-dose group C.

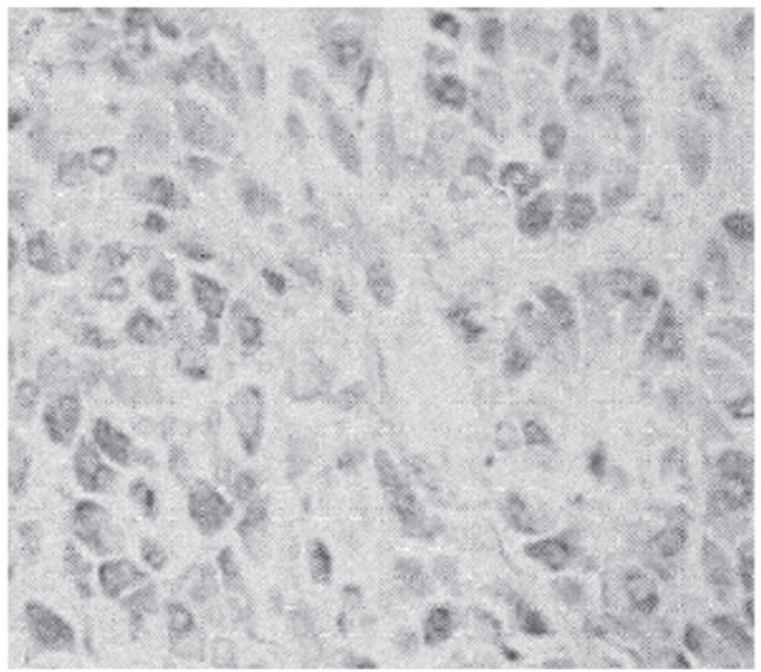

Figure 4. IL-10 local expression in pancreatic tissues (hematoxylin and eosin, $\mathrm{x} 400$ ) of mice in control group D.

of lymphocyte improved and pancreatic islet size was restored somewhat.

Local expression of IL-10 in pancreatic tissues. Under the light microscope, numerous brown granules with deep color within pancreatic sample cells in exendin-4 low-dose group A, medium-dose group B and high-dose group C (Figs. 1-3) were observed. There were a few brown granules within pancreatic sample cells in control group D (Fig. 4). IL-10 immunohistochemistry scores in low-dose group A, medium-dose group B and high-dose group C were $3.82 \pm 0.72,4.34 \pm 0.86$ and $4.81 \pm 0.94$, respectively, all of which were higher than the immunohistochemistry score of $2.25 \pm 0.63$ in group D.

Test results of FCM. The $\mathrm{CD} 4+\mathrm{CD} 25+\mathrm{T}-$ cell proportions in pancreatic tissues in exendin-4 low-dose group A, medium-dose group B and high-dose group C were 5.31, 
Table I. Comparison of serum IL-2, IL-10 and IFN- $\gamma$ in the four groups.

\begin{tabular}{lcccc}
\hline Group & No. & IL-2 $(\mathrm{pg} / \mathrm{ml})$ & IL-10 $(\mathrm{pg} / \mathrm{ml})$ & IFN- $\gamma(\mathrm{pg} / \mathrm{ml})$ \\
\hline Low-dose group A & 10 & $61.12 \pm 9.48^{\mathrm{a}}$ & $195.67 \pm 20.15^{\mathrm{a}}$ & $321.36 \pm 28.26^{\mathrm{a}}$ \\
Medium-dose group B & 10 & $58.36 \pm 8.97^{\mathrm{a}, \mathrm{b}}$ & $213.92 \pm 21.84^{\mathrm{a}, \mathrm{b}}$ & $303.46 \pm 25.37^{\mathrm{a}, \mathrm{b}}$ \\
High-dose group C & 10 & $53.15 \pm 8.26^{\mathrm{a}-\mathrm{c}}$ & $238.72 \pm 23.34^{\mathrm{a}-\mathrm{c}}$ & $285.48 \pm 22.65^{\mathrm{a}-\mathrm{c}}$ \\
Control group D & 10 & $81.34 \pm 10.27$ & $162.66 \pm 18.37$ & $363.57 \pm 31.28$ \\
\hline
\end{tabular}

Compared with control group $\mathrm{D}^{\mathrm{a}}, \mathrm{P}<0.05$; compared with low-dose group $\mathrm{A}^{\mathrm{b}}, \mathrm{P}<0.05$; compared with medium-dose group $\mathrm{B}^{\mathrm{c}}, \mathrm{P}<0.05$.

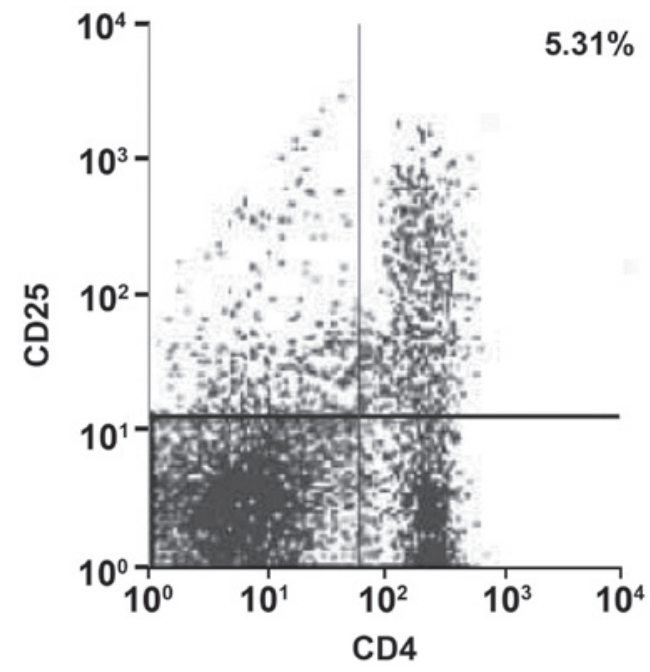

Figure 5. Variation of mouse pancreatic CD4+CD25+T-cell subset proportion in low-dose group A.

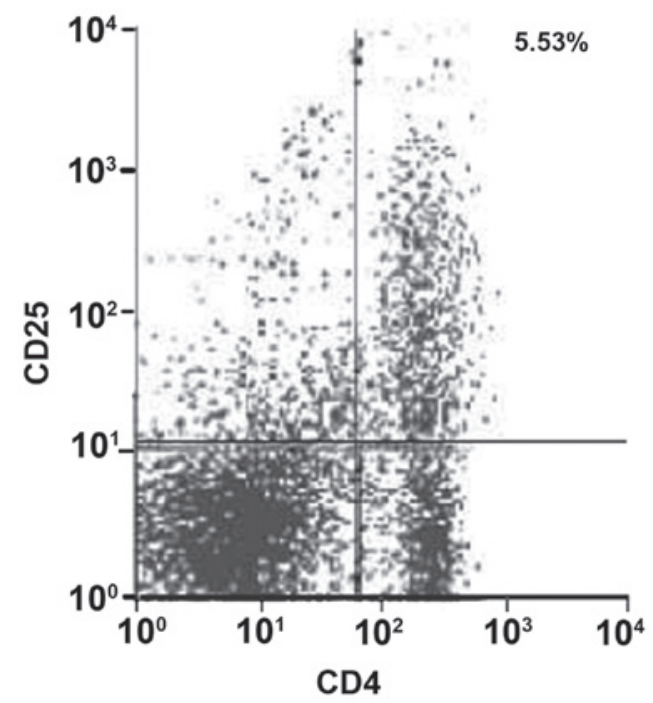

Figure 6. Variation of mouse pancreatic $\mathrm{CD} 4+\mathrm{CD} 25+\mathrm{T}-\mathrm{cell}$ subset proportion in medium-dose group B.

5.53 and $5.74 \%$, respectively, all of which were higher than the $\mathrm{CD} 4+\mathrm{CD} 25+\mathrm{T}$-cell proportions of $1.62 \%$ in group $\mathrm{D}$, as shown in Figs. 5-8 (right upper quadrant of each figure was a $\mathrm{CD} 4+\mathrm{CD} 25+\mathrm{T}$ cell subset). The proportions of $\mathrm{CD} 4+\mathrm{CD} 25^{\text {high }}$ $\mathrm{T}$-cells in CD4+T cells increased in groups A, B and C.

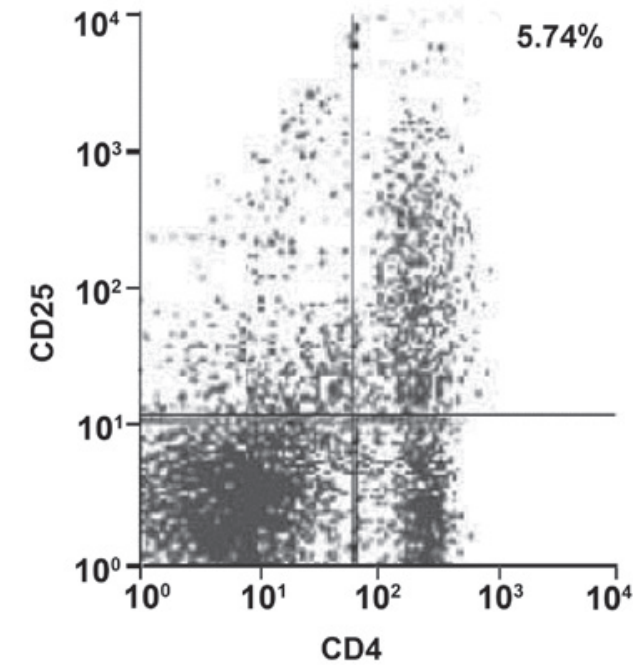

Figure 7. Variation of mouse pancreatic $\mathrm{CD} 4+\mathrm{CD} 25+\mathrm{T}-$ cell subset proportion in high-dose group C.

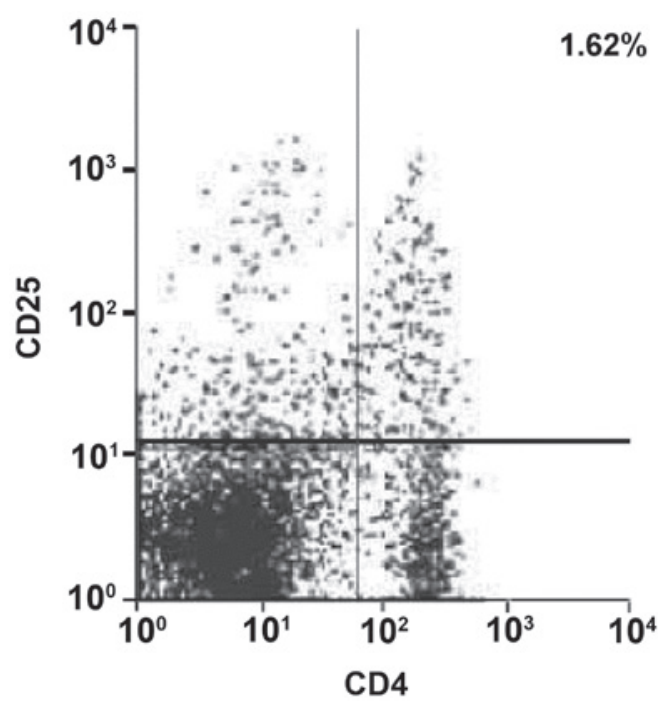

Figure 8. Variation of mouse pancreatic CD4+CD25+T-cell subset proportion in control group D.

Comparison of serum IL-2, IL-10 and IFN- $\gamma$. Compared with control group D, serum IL-10 levels in exendin-4 low-dose group A, medium-dose group B and high-dose group $\mathrm{C}$ increased $(\mathrm{P}<0.05)$, while IL-2 and IFN- $\gamma$ levels decreased $(\mathrm{P}<0.05)$. The difference of serum IL-10, IL-2 and 
IFN- $\gamma$ levels existing in IFN- $\gamma$ was of statistical significance $(\mathrm{P}<0.05)$ (Table I).

\section{Discussion}

Previous findings have shown that the occurrence of type 1 diabetes involves phases such as cellular imbalance, inflammatory cell recruitment and inflammatory cell effect (8). The classical immunoregulation imbalance theory states that, the imbalance of Th1/Th2 cell subset and disorder of body immunologic functions are key factors inducing type 1 diabetes $(9,10)$. IL-2, IFN- $\gamma$ and others are common Th1 cell factors that can upregulate pro-inflammatory factors, thus generating damage on pancreatic $\beta$ cells. IL-10, IL- 4 and others belong to Th 2 cell factors, which can downregulate the activity of Th1 cells and have a preventative effect on type 1 diabetes (11). The present study has shown that compared with control group D, serum IL-10 levels in exendin-4 low-dose group A, medium-dose group $\mathrm{B}$ and high-dose group $\mathrm{C}$ increased $(\mathrm{P}<0.05)$, while IL-2 and IFN- $\gamma$ levels decreased $(\mathrm{P}<0.05)$. The difference of the serum IL-10, IL-2 and IFN- $\gamma$ levels existing among IFN- $\gamma$ were of statistical significance $(\mathrm{P}<0.05)$. Thus, it can be seen that exendin-4 intervention can reduce the expression of NOD mouse serum IL- 2 and IFN- $\gamma$, elevate the expression of serum IL-10 and exert a protective effect on pancreatic $\beta$ cells.

$\mathrm{T}$ lymphocytes are closely related to diabetes pancreatitis. The inflammatory reaction induced by cell factors that are released by body $\mathrm{CD} 4+\mathrm{T}$ lymphocytes and cell toxic reaction mediated by body CD8+T lymphocytes are considered the main forms of cellular immunity induced by $\mathrm{T}$ lymphocytes (12-14). If CD4+T lymphocyte subsets gradually increase, then multiple types of cell factors can be released. While these cell factors, may enhance the inflammatory reaction of lymphocyte infiltration, form lethal effects on antigens and generate adverse effects, they also can facilitate cellular immunity and humoral immunity to a certain degree, and then promote effective removal of virus in vivo. Regulatory T-cells $\left(\mathrm{CD} 4+\mathrm{CD} 25^{\text {high }}\right.$ Foxp3+T reg) are a type of T-cell subset with immunomodulating functions that has been verified in recent years. It can maintain self-stabilization of an immune system while regulating the immune response (15-17). The present study has shown that CD4+CD25+T-cell proportions in pancreatic tissues of exendin-4 low-dose group A, medium-dose group B and high-dose group $\mathrm{C}$ were 5.31 , 5.53 and $5.74 \%$, respectively, all of which were higher than the CD4+CD25+T-cell proportion of $1.62 \%$ in control group D. CD4+CD25 $5^{\text {high }} \mathrm{T}$-cells in groups $\mathrm{A}, \mathrm{B}$ and $\mathrm{C}$ occupied an increasing proportion in CD4+T-cells. Studies have indicated that $\mathrm{CD} 4+\mathrm{CD} 25^{\text {high }} \mathrm{T}$ increased in NOD tumor infiltration lymphocytes under exendin-4 intervention, which may be associated with the fact that it exerted an immunosupressive effect by inhibiting the lethal effects of CD8+T cells through contact among cells (18).

Previous studies reported that, IL-10 can reduce the accumulated morbidity of diabetes, lower the inflammation degree of pancreas islets and relieve or prevent the occurrence and development of type 1 diabetes $(19,20)$. Notably diabetes is rarely diagnosed in an early phase. The lymphocyte infiltration degree may be serious once the patient is diagnosed with diabetes, and there are quite a few residual pancreatic $\beta$ cells (21). The present findings have shown that pancreatitis of mice in control group D was mainly at grade 2 and 3 , and under a light microscope, it was observed that pancreatic cell morphology was in disorder and the size and quantity of the pancreas was small. Pancreatitis in exendin-4 low-dose group A, medium-dose group B and high-dose group $\mathrm{C}$ was mainly at grade 0 and 1 , and light microscopy showed that pancreatic cell morphology and lymphocyte infiltration improved, and the size of the pancreas was recovered. Additionally, a few brown granules with deep color were found within the pancreatic sample cells in control group D. IL-10 immunohistochemistry scores in low-dose group A, medium-dose group B and high-dose group $\mathrm{C}$ were $(3.82 \pm 0.72),(4.34 \pm 0.86)$ and $(4.81 \pm 0.94)$, respectively, all of which were higher than that in control group D $(2.25 \pm 0.63)$. We conjectured that exendin-4 intervention elevates IL-10 levels in pancreatic tissues, downregulates bioactivity of Th1 cell factors through overexpression of IL-10, is regulated in the in vivo immune microenvironment and prevents the occurrence and development of diabetes.

In summary, NOD mouse body immune function is low, while the regulatory mechanism of its body immunity is in a state of disorder. Pancreatic tissue necrosis and inflammatory infiltration are serious. Exendin-4 intervention can exert certain regulatory effects on the IL-2, IFN- $\gamma$, IL-10 and T lymphocyte subset of NOD mice. By reducing the expression of serum IL- 2 and IFN- $\gamma$, it elevates IL-10 expression in serum and pancreatic tissues and increases the quantity of CD8+, CD4+ and CD25+ T cells in pancreatic tissues, thus eliminating inflammatory factors, boosting pancreatic tissue recovery and improving lymphocyte infiltration degree. Thus, the results of the current study, revealed the mechanism involved in exendin-4 on NOD mouse blood and the pancreatic tissue immune microenvironment.

\section{Acknowledgements}

The present study was funded by the Natural Science Foundation of Fujian province (grant no. 2016J01650).

\section{References}

1. Lind K, Hühn MH and Flodström-Tullberg M: Immunology in the clinic review series; focus on type 1 diabetes and viruses: The innate immune response to enteroviruses and its possible role in regulating type 1 diabetes. Clin Exp Immunol 168: 30-38, 2012.

2. Spinale FG and Stolen CM: Biomarkers and heart disease: What is translational success? J Cardiovasc Transl Res 6: 447-448, 2013.

3. Diana $\mathbf{J}$ and Lehuen A: Macrophages and $\beta$-cells are responsible for CXCR2-mediated neutrophil infiltration of the pancreas during autoimmune diabetes. EMBO Mol Med 6: 1090-1104, 2014.

4. Muller O, Ntalianis A, Winjs W, Delrue L, Dierickx K, Auer R, Rodondi N, Mangiacapra F, Trana C, Hamilos M, et al: Association of biomarkers of lipid modification with functional and morphological indices of coronary stenosis severity in stable coronary artery disease. J Cardiovasc Transl Res 6: 536-544, 2013.

5. Skyler JS: Prevention and reversal of type 1 diabetes - past challenges and future opportunities. Diabetes Care 38: 997-1007, 2015.

6. Kaminitz A, Mizrahi K, Ash S, Ben-Nun A and Askenasy N: Stable activity of diabetogenic cells with age in NOD mice: Dynamics of reconstitution and adoptive diabetes transfer in immunocompromised mice. Immunology 142: 465-473, 2014. 
7. Savinov AY and Strongin AY: Targeting the T-cell membrane type-1 matrix metalloproteinase-CD44 axis in a transferred type 1 diabetes model in NOD mice. Exp Ther Med 5: 438-442, 2013.

8. Chen YG, Forsberg MH, Khaja S, Ciecko AE, Hessner MJ and Geurts AM: Gene targeting in NOD mouse embryos using zinc-finger nucleases. Diabetes 63: 68-74, 2014

9. Rachmiel M, Bloch O, Bistritzer T, Weintrob N, Ofan R, Koren-Morag N and Rapoport MJ: TH1/TH2 cytokine balance in patients with both type 1 diabetes mellitus and asthma. Cytokine 34: 170-176, 2006.

10. Nikoopour E, Schwartz JA, Huszarik K, Sandrock C, Krougly O, Lee-Chan E and Singh B: Th17 polarized cells from nonobese diabetic mice following mycobacterial adjuvant immunotherapy delay type 1 diabetes. J Immunol 184: 4779-4788, 2010.

11. Hill T, Krougly O, Nikoopour E, Bellemore S, Lee-Chan E, Fouser LA, Hill DJ and Singh B: The involvement of interleukin-22 in the expression of pancreatic beta cell regenerative Reg genes. Cell Regen (Lond) 2: Apr 4, 2013 (Epub ahead of print). doi: 10.1186/2045-9769-2-2.

12. Vong AM, Daneshjou N, Norori PY, Sheng H, Braciak T, Sercarz EE and Gabaglia CR: Spectratyping analysis of the islet-reactive $\mathrm{T}$ cell repertoire in diabetic NOD $\operatorname{Ig} \mu$ (null) mice after polyclonal B cell reconstitution. J Transl Med 9: 1-10, 2011.

13. Costa N, Pires AE, Gabriel AM, Goulart LF, Pereira C, Leal B, Queiros AC, Chaara W, Moraes-Fontes MF, Vasconcelos C, et al: Broadened T-cell repertoire diversity in ivIg-treated SLE patients is also related to the individual status of regulatory T-cells. J Clin Immunol 33: 349-360, 2013.

14. Ablamunits V, Henegariu O, Hansen JB, Opare-Addo L, Preston-Hurlburt P, Santamaria P, Mandrup-Poulsen T and Herold KC: Synergistic reversal of type 1 diabetes in NOD mice with anti-CD3 and interleukin-1 blockade: Evidence of improved immune regulation. Diabetes 61: 145-154, 2012.
15. Kim J, Shon E, Kim CS and Kim JS: Renal podocyte injury in a rat model of type 2 diabetes is prevented by metformin. Experimental Diabetes Research 2012; Sep 27, 2012 (Epub ahead of print). doi: 10.1155/2012/210821.

16. Kachapati K, Bednar KJ, Adams DE, Wu Y, Mittler RS, Jordan MB, Hinerman JM, Herr AB and Ridgway WM: Recombinant soluble CD137 prevents type one diabetes in nonobese diabetic mice. J Autoimmun 47: 94-103, 2013.

17. Suryani S, Evans K, Richmond J and Lock RB: Evaluation of the Bcl-2 inhibitor ABT-199 in xenograft models of acute lymphoblastic leukemia by the pediatric preclinical testing program. Cancer Res 75: 3276, 2015.

18. Marino E, Villanueva J, Walters S, Liuwantara D, Mackay F and Grey ST: CD4(+)CD25(+) T-cells control autoimmunity in the absence of B-cells. Diabetes 58: 1568-1577, 2009.

19. Zhang YJ, Li S, Gan RY, Zhou T, Xu DP and Li HB: Impacts of gut bacteria on human health and diseases. Int J Mol Sci 16: 7493-7519, 2015

20. Zechner D, Spitzner M, Bobrowski A, Knapp N, Kuhla A and Vollmar B: Diabetes aggravates acute pancreatitis and inhibits pancreas regeneration in mice. Diabetologia 55: 1526-1534, 2012.

21. Attinkara R, Mwinyi J, Truninger K, Regula J, Gaj P, Rogler G, Kullak-Ublick GA and Eloranta JJ; Swiss IBD Cohort Study Group: Association of genetic variation in the NR1H4 gene, encoding the nuclear bile acid receptor FXR, with inflammatory bowel disease. BMC Res Notes 5: 1-12, 2012. 